\title{
Antitumour effects of aminobisphosphonates on renal cell carcinoma cell lines
}

\author{
Hardev Pandha Senior Lecturer in Medical Oncology \\ Lindsay Birchall Research Technician \\ Brendan Meyer Research Technician \\ Natalie Wilson Post Doctoral Fellow \\ Kate Relph Research Fellow \\ Christopher Anderson* Consultant Urologist \\ Kevin Harrington** Senior Lecturer in Clinical Oncology
}

Department of Oncology and Urology* St George's Hospital Medical School, Cranmer Terrace, London SW17 ORE, United Kingdom

Tel 020-87251255 ext 0809, Fax 020-87250158

**Targeted Therapy Laboratory, Cancer Research UK Centre for Cell and Molecular Biology, Institute of Cancer Research, Fulham Road, London, SW3 655, United Kingdom Tel/Fax 02073528133

Correspondence to Dr Hardev Pandha E mail hpandha@sghms.ac.uk

Keywords: aminobisphosphonates, carcinoma, renal, cell lines. 


\section{Abstract}

Purpose Bisphosphonates are established as a supportive therapy for a number of malignancies which metastasise to bone. Previous reports also suggest potent antitumour and antiangiogenic properties. We investigated the in vitro activity of two aminobisphosphonates, pamidronate (PAM) and zoledronic acid (ZOL) on the growth and survival of three renal cell carcinoma cell lines (Caki-2, 769-P and D69581). Experimental design Cell lines were exposed to bisphosphonates in vitro and evaluated by MTS (3-(4,5-dimethylahiazol-2-yl)-5-(3-carboxymethoxyphenyl)-2-(4sulfophenyl)-2H-tetrazolium) assay and cell cycle analysis. Mechanisms of apoptotic cell death was investigated by Apo-Direct assay, western blot and by Kinetworks ${ }^{\mathrm{TM}}$ Analyses

Results ZOL was consistently more potent than PAM in inducing apoptotic cell death. ZOL was capable of overcoming resistance to PAM in one cell line. Addition of isoprenoids only partially reduced the effects of ZOL and PAM. Although ultimately less potent, the inhibitory effects of PAM appear earlier than ZOL. The proapototic effect of ZOL was through non-mitochondrial pathways and was associated with activation of caspase 6, caspase 3 and PARP (poly ADPribosyltransferase polymerase) cleavage. Furthermore, we observed a marked reduction in, and intracellular distribution of, $\mathrm{MSH}$, a protein involved in DNA mismatch repair, as well as evidence of a greater cellular response to ZOL as increased expression of superoxide dismutase.

Conclusion These findings add further support to the clinical use of aminobisphosphonates, particularly ZOL, for RCC patients with metastatic disease to bone. 


\section{Introduction}

There are no satisfactory treatment options for renal cell carcinoma (RCC) in the advanced stage; even palliation of symptoms is problematic due to the inherent chemo- and radio-resistance of RCC. The incidence of renal cell carcinoma has been increasing steadily over the last twenty years and has been estimated that bone metastases will develop in approximately $30 \%$ of patients (1). Bony involvement may lead to considerable morbidity including bone pain, pathological fractures, hypercalcemia and spinal cord compression (2). It has been reported that approximately $81 \%$ of patients with RCC with bone metastases require radiotherapy. Of these patients $42 \%$ experience long bone fracture and $29 \%$ require orthopaedic surgery or develop hypercalcemia at some point during the course of their disease (1). Bone metastases associated with RCC rarely respond to systemic treatment.

Bisphosphonates (BP) are analogues of endogenous pyrophosphate and inhibit bone reabsorption at the level of the osteoclast. They have become increasingly useful in patients with metastatic bone disease. BP have been used extensively in the treatment of postmenopausal osteoporosis (3), corticosteroid-induced bone loss (4), Pagets disease (5), patients with hypercalcemia of malignancy, and in the prevention of skeletal complications associated with bony metastases in patients with multiple myeloma and breast cancer (6-10). Although not associated with improved overall survival in any malignancy, intravenous zoledronate (ZOL) has also been shown to reduce the percentage of patients experiencing skeletal related events in a range of other malignancies including renal cell carcinoma, lung cancer and prostate cancer (11) (12) (13) and breast cancer and multiple myeloma.

Several recent studies have suggested that these compounds have not only strong antiosteoclastic activity, but also a direct antitumour effect. Aminobisphosphonates inhibit squalene synthase (14), disrupt prenylation of small GTP proteins (15), inhibit tyrosine phosphatase activity (16) and reduce invasion and adhesion by disruption of matrix metalloproteinase secretion (17). BP may also be capable of interfering with growth and survival of metastatic cancer cells in bone (18) (19) (20) by altering the release of growth factors into in the bone microenvironment. They may also exert an antiangiogenic effect (21). In addition, aminobisphosphonates have been found to 
dramatically increase apoptosis in macrophage, myeloma-derived, prostate and pancreatic cancer cell lines $(22,23)(24)$

Third generation nitrogen-containing BP such as ZOL inhibit farnesyldiphosphate synthase, an enzyme involved in the mevalonate pathway preventing the posttranslational events of prenylation of small GTP-binding proteins such as $\mathrm{p} 21$ ras. Rab, Rho, Rac abd cdc42 (15), required for functions such as signal transduction and cell adhesion. There are reports of synergy with chemotherapy and biological therapies (25) (26)

A number of studies have reported on the effects of BP directly on growth and survival of cancer cell lines derived from solid malignancies. ZOL induces a reduction in cell viability, increased apoptotic death and downregulation of bcl-2, p21 ras delocalization from the cell membrane and proteolytic cleavage of PARP, indicating direct antitumour effects in breast cancer cell lines (27). In prostate cancer, ZOL inhibited cell proliferation by induction of cell death and /or cytostasis in vitro (28). In pancreatic cancer lines, commonly associated with $\mathrm{p} 21$ ras dysregulation, the effects of BP was to interfere with growth and survival pathways downstream of p21 ras. ZOL treatment resulted in apoptotic death and caspase 9 (but not caspase 3) activation (24).

In this study we have evaluated the effect of two aminobisphosphonates, pamidronate (PAM) and zoledronate (ZOL) on the growth and survival of three RCC cell lines in vitro. Although the frequency of KRAS mutation is low in RCC, this evaluation was proposed based on the observation of activated HRAS oncogenes in human RCC with single point mutations within codon 12 and 61, and the reported clinical effects of zoledronic acid in RCC (29) (30) (31). Two of the three cell lines were sensitive to both PAM and ZOL; both agents were capable of significant growth inhibition and inducing cell death. The third cell line showed a differential sensitivity to BP with resistance to even prolonged exposure to PAM and failure of caspase 3 activation. This cell line was studied in more detail using an apoptosis protein screening assay to gain more insight into the mechanism of apoptotic death in the cells susceptible to ZOL. 


\section{Materials and Methods}

\section{Cell Lines}

Human renal cell lines 769-P, Caki-2 were obtained from ATCC. The cell lines were derived from primary clear cell adenocarcinomas (769-P and Caki-2) or from lymph node metastasis of a clear cell adenocarcinoma (D69581). 769P and MCF-7 were maintained in RPMI-1640, 10\% FCS, $2.05 \mathrm{mM} \mathrm{L-Glutamine,} 100 \mathrm{U} / \mathrm{ml}$ penicillin and $0.1 \mathrm{mg} / \mathrm{ml}$ streptomycin. Caki-2 was maintained in McCoy's 5A, 10\% FCS, $1.5 \mathrm{mM}$ L-Glutamine, $100 \mathrm{U} / \mathrm{ml}$ penicillin and $0.1 \mathrm{mg} / \mathrm{ml}$ streptomycin. Human renal cell line D69581 was a gift from Onyvax Ltd and was maintained in DMEM, 10\% FCS, 4 mM L-Glutamine, $100 \mathrm{U} / \mathrm{ml}$ penicillin and $0.1 \mathrm{mg} / \mathrm{ml}$ streptomycin. All cell lines were maintained at $37^{\circ} \mathrm{C}$ in a humidified $5 \% \mathrm{CO}_{2}$ environment and were routinely screened for mycoplasma contamination.

\section{Bisphosphonate Dosage Studies}

Tumour cells were allowed to grow to $80 \%$ confluency, were washed once in PBS and removed from plates with trypsin/EDTA. Trypsin/EDTA activity was stopped by adding fresh medium and FCS. Cells were seeded at a density of $1 \times 10^{4}$ in 96 -well plates and allowed to adhere overnight. Media was then replaced with $100 \mu \mathrm{l} /$ well serum-free media containing various concentrations $(0,10$ and $100 \mu \mathrm{M})$ of $\mathrm{ZOL}$ (Novartis) and PAM (Faulding Pharmaceuticals plc). For comparison, the effects of first generation bisphosphonate clodronate (Sigma UK)was used. Clodronate lacks primary and tertiary amino groups which PAM and ZOL contain respectively. At time points 30 minutes, 1 hour, 3 hours, 24 hours, 48hours and 72 hours after drug addition, $20 \mu \mathrm{l} /$ well CellTiter $96^{\circledR}$ Aqueous One Solution reagent (Promega, UK) was added and after a further 1-4 $\mathrm{h}$ incubation plates were read at $450 \mathrm{~nm}$. In some experiments the drugs were replaced by normal media after 6 and $24 \mathrm{~h}$, and the MTS assay performed $72 \mathrm{~h}$ after initial drug addition. The optical density (OD $450 \mathrm{~nm}$ ) of media plus CellTiter $96^{\circledR}$ Aqueous One Solution reagent was subtracted from all readings and results calculated as $\%$ viable cells. 


\section{Apo-Direct Assay}

Tumour cells were seeded into flasks and allowed to adhere overnight. Media was then replaced with serum free media containing either no drug, ZOL or PAM. $72 \mathrm{~h}$ after drug addition floating and adherent cells were harvested, combined and fixed with $10 \%$ paraformaldehyde and stored at $-20^{\circ} \mathrm{C}$ in $70 \%$ ethanol, according to the manufacturer,s instructions. DNA breaks in the cells were then labelled with FITCdUTP following manufacturer's instructions and samples were analysed on a FACScan machine. Data was analysed using WinMDi (Scripps).

\section{Cell Lysis and SDS-PAGE}

Cells were treated with no drug, $100 \mu \mathrm{M}$ ZOL or $100 \mu \mathrm{M}$ PAM for $72 \mathrm{~h}$. Adherent and non-adherent cells were harvested into cold PBS, washed and resuspended in lysis buffer (50 mM Trizma, $150 \mathrm{mM} \mathrm{NaCl,} \mathrm{0.1 \%} \mathrm{v/v} \mathrm{Triton} \mathrm{X-100,} 0.8 \mu \mathrm{g} / \mathrm{ml}$ aprotinin, $3 \mu \mathrm{g} / \mathrm{ml}$ PMSF) and incubated on ice for $2 \mathrm{~h}$. The cell lysates were microfuged at full speed for $10 \mathrm{~min}$ at $4^{\circ} \mathrm{C}$ to remove cell debris, and the supernatants aliquoted and stored at $-80^{\circ} \mathrm{C}$. Protein concentration was estimated using Bio-Rad Protein Assay with bovine serum albumin standards following the microassay procedure in the manufacturer's instructions.

Approximately $25 \mu \mathrm{g}$ of protein/well was run by SDS-PAGE on a 12\% resolving gel and transferred to Hybond-C Extra nitrocellulose membrane.

\section{Protein Detection}

$\beta$-actin was detected using the Actin (Ab-1) Kit (Oncogene ${ }^{\mathrm{TM}}$ Research Products). Bax was detected using a rabbit polyclonal Anti-Bax antibody (Santa Cruz Biotechnology, Inc) at a dilution of 1:200 and the anti-rabbit IgG-HRP secondary Ab from the ECL ${ }^{\text {TM }}$ Western Blotting System (Amersham, UK). Bcl-2 was detected using a mouse monoclonal Anti-Bcl-2 antibody (Santa Cruz Biotechnology, Inc) at a dilution of 1:100 and the anti-mouse IgG-HRP secondary Ab from the ECL ${ }^{\mathrm{TM}}$ Western Blotting System. Inducible heat shock protein 70 (iHsp70) was detected using mouse Anti-Hsp70 monoclonal antibody (Stressgen \#SPA-810) at a dilution of 1:1000 and the anti-mouse IgG-HRP secondary Ab from the ECL TM Western Blotting System. The ECL ${ }^{\mathrm{TM}}$ Western Blotting System was used to visualise both proteins. 


\section{Kinetworks $^{\mathrm{TM}}$ Analyses}

For the preparation of cytosolic fractions for Kinetworks ${ }^{\mathrm{TM}}$ analyses, cells were homogenized using a Dounce homogenizer in lysis buffer without $\mathrm{NaCl}$ and Nonidet P-40. The lysis buffer consisted of the following: $20 \mathrm{mM}$ MOPS pH 7.0, $2 \mathrm{mM}$ EGTA, 5 mM EDTA, $30 \mathrm{mM}$ sodium fluoride, $40 \mathrm{mM} \beta$-glycerophosphate $\mathrm{pH}$ 7.2, 10 $\mathrm{mM}$ sodium pyrophosphate, $2 \mathrm{mM}$ sodium orthovanadate, $1 \mathrm{mM}$ phenylmethylsulfonylfluoride, $3 \mathrm{mM}$ benzamidine, $5 \mu \mathrm{M}$ pepstatin $\mathrm{A}, 10 \mu \mathrm{M}$ leupeptin. After ultracentrifugation at $100,000 \mathrm{rpm}$ for $30 \mathrm{~min}$ at $4{ }^{\circ} \mathrm{C}$, the supernatant was collected as a cytosolic fraction. The pellet fraction was then rehomogenized in lysis buffer with $\mathrm{NaCl}$ and $0.5 \%$ Nonidet P-40. After ultracentrifugation, the detergent-solubilized supernatant was saved as a particulate fraction. Kinetworks ${ }^{\mathrm{TM}}$ analyses were performed on 300-600 $\mu \mathrm{g}$ of protein/sample. The immunoblotting analyses involved probing with mixes of in-house validated primary antibodies from commercial sources and the application of each mix into a separate lane of a 20-lane multiblotter (Immunetics). Detailed protocols for the Kinetworks ${ }^{\mathrm{TM}}$ analyses can be found at the Kinexus Bioinformatics website (www.kinexus.ca).

\section{Caspase-3 Assay}

Caki-2 cells were treated with no drug, $100 \mu \mathrm{M}$ ZOL or $100 \mu \mathrm{M}$ PAM for $72 \mathrm{~h}$. Adherent and non-adherent cells were harvested into cold PBS, washed and resuspended in lysis buffer (10 mM HEPES pH 7.3, 2 mM EDTA, 0.1\% NP40, 5 mM DTT, $1 \mathrm{mM}$ PMSF, $10 \mu \mathrm{g} / \mathrm{ml}$ pepstatin A, $10 \mu \mathrm{g} / \mathrm{ml}$ leupeptin, $10 \mu \mathrm{g} / \mathrm{ml}$ aprotinin) and incubated on ice for $15 \mathrm{~min}$. The cell lysates were microfuged at full speed for 10 min at $4{ }^{\circ} \mathrm{C}$ to remove cell debris, and the supernatants aliquoted and stored at $-80^{\circ} \mathrm{C}$. Protein concentration was estimated using Bio-Rad Protein as described above. Approximately $18 \mu \mathrm{g}$ of protein in a $20 \mu \mathrm{l}$ volume was added to $178 \mu \mathrm{l}$ reaction buffer (100 mM HEPES pH 7.3, 20\% v/v glycerol, 0.5 mM EDTA, 5 mM DTT)in triplicate in a black 96-well plate. $2 \mu 1$ of caspase-3 substrate Ac-DEVD-AMC $5 \mathrm{mM}$ in 4\% DMSO (BioSource) was added. Free AMC was measured using a Packard Fusion fluorometer with a $380 \mathrm{~nm}$ excitation and a $460 \mathrm{~nm}$ emission filter, over a time course. Background fluorescence (reaction buffer/substrate alone) was subtracted and fluorescence units plotted against time. Results shown represent AMC release over a 
$1 \mathrm{~h}$ period of the straight-line portion of the graph and are calculated as a percentage of "no drug".

\section{Assessment of the effects of farnesyl transferase inhibitor and isoprenoids}

Farnesol mixed isomers (FOH, 3,7,11-trimethyl-2,6,10-dodecatrien-1-ol) and geranylgeraniol (GGOH, 3,7,11,15-tetramethyl-2,6,10,14-hexadecatetraen-1-ol) (both from Sigma, Poole, UK), as cell permeable analogues of FPP and GGPP, were added to cells 3 hours before treating with zoledronic acid, to bypass any suppression of prenylation caused by inhibition of the mevalonate pathway. Both were reconstituted in $100 \%$ ethanol. Manumycin A (Sigma, UK) wasused to directly inhibit protein prenylation, and compare the results with zoledronic acid. Manumycin A is a naturally occurring farnesyltransferase inhibitor (FTI) All reagents were diluted in culture medium before adding to cell cultures.

\section{Detection of MSH2 protein}

Cells were seeded at a density of $1 \times 10^{5}$ on $12 \mathrm{~mm}$ poly-L-lysine coated glass coverslips (BD Biosciences) and allowed to adhere overnight. After a brief rinse in PBS, the coverslips were immersed in ice-cold methanol and incubated at $-20^{\circ} \mathrm{C}$ for 10 min. The coverslips were air dried, rinsed with PBS and covered with blocking buffer $(1 \% \mathrm{BSA}, 1 \%$ human $\mathrm{AB}$ serum in $\mathrm{PBS})$ for $30 \mathrm{~min}$ at $37^{\circ} \mathrm{C}$. Blocking buffer was removed by aspiration and the coverslips were incubated with diluted anti-MSH2 and relevant isotype control (BD Biosciences) for 1 hour at room temperature in the dark. The coverslips were washed three times in PBS (5 min) and incubated with diluted FITC-conjugated secondary antibody for $1 \mathrm{~h}$ at room temperature in the dark. The coverslips were washed three times in PBS ( 5 min) and images were collected on a Zeiss Axiovert 135 fluorescence microscope equipped with a Hamamatsu high resolution digital camera. 


\section{Results}

The effect of ZOL and PAM on the proliferation of renal carcinoma cell lines. The effect of ZOL and PAM on 769-P, Caki-2 and D69581 cells was investigated using the MTS assay. The cell lines were exposed to between 0 and $100 \mu \mathrm{mol}$ of ZOL and 0 and $200 \mu \mathrm{mol}$ PAM, and assessments made at a time points between 30 minutes and 72 hours as recent reports with pancreatic cell lines indicated that very short exposures to bisphosphonate may affect their proliferation. There was differential sensitivity of cell lines to each of the compounds. We compared the effects clodronate on the same cell lines. All three lines eventually succumbed to the drug but at markedly high doses ( $>2000 \mathrm{mM})$, once again Caki-2 appeared to be least susceptible Figure 1. Caki 2 appeared to be generally resistant to both ZOL and PAM at 48 hours, but after 72 hours was only susceptible to ZOL at the highest dose. Increasing dose and time of exposure to PAM (over $200 \mu \mathrm{mol}$ and beyond 72 hours) did not result in any additional antiproliferative effects on this cell line (data not shown). D69581 appeared to be the most sensitive cell line to exposure to either bisphosphonate with loss of cell viability observed even after 30 minutes exposure. Both ZOL and PAM had activity on the 769-P cell line, with more pronounced cell kill with ZOL after 72 hour exposure. ZOL had a more pronounced antiproliferative effect at lower concentrations. In 769P and D69581 cells, we noted that although the onset of the effects of PAM appeared earlier than ZOL, ZOL appeared to be more effective overall and exerted its maximal effect after more prolonged drug exposure. The maximal response to PAM appeared to be 48 hours and 1 hour respectively in these two lines, but by 72 hours there was evidence of significant cell proliferation to the lower doses of PAM. Figure 2.

The effects of isoprenoid lipid analogues on bisphosphonate treatment Several studies have suggested that amino-containing bisphosphonates cause apoptosis by preventing post-translational modification of GTP-binding proteins with isoprenoid lipids. The possible role of protein prenylation was examined in our cell lines. Farnesyltransferase inhibition using manumycin resulted in cell death in all cell lines after 24 hours after exposure to $20 \mu \mathrm{M}$ manumycin (data not shown). FOH and 
GGOH can be used intracellularly for protein prenylation through a salvage pathway. The addition of FOH and GGOH only partially attenuated the effects of ZOL (statistically significant for the addition of FOH) but not PAM at 24 hours. Figure 3.

\section{Assessment of mode of cell death}

After exposure to bisphosphonate at $100 \mu \mathrm{mol}$ (or no drug) for 72 hours, cells were harvested, fixed and stained for DNA fragmentation using FITC-dUTP. ZOL exposure resulted in high levels of apoptosis for the 769-P and D69581 lines (over 80\%) with lower levels in the Caki-2 line ((39.67+/-9.10). Exposure to PAM resulted in apoptotic death in D69581 and 769-P cells but at lower levels that with ZOL treatment. Caki-2 cells were resistant to PAM at this and higher concentrations. Table 1. Morphological changes in each cell line after exposure to ZOL and PAM is shown in figure 4.

\section{Cell cycle analysis}

We investigated the effects of BP on the cell cycle using flow cytometry. Figure 5. Cell cycle analysis was performed on untreated control cells and after 72 hour exposure to ZOL and PAM. Each experiment was repeated at least five times. Untreated controls had few cells in the apoptotic peak, and had a distribution in the sub G1, G1, S and G2/M phases typical of proliferating cancer cells. For 769P there was a reduction in G1 (more pronounced with PAM), increase in S phase (more pronounced with PAM) and increase in G2/M (more pronounced with PAM). For D69581, an increase in sub G1 with ZOL was observed but again reduction in $\mathrm{G} 1$ and increase in $\mathrm{S}$ phase and $\mathrm{G} 2 / \mathrm{M}$ much more pronounced with PAM than ZOL. Finally PAM had little effect on cell cycle on Caki-2 lines as expected, ZOL exposure resulted in marked increase in subG1 and a lesser increase in S phase and $\mathrm{G} 2 / \mathrm{M}$.

\section{Mechanism of apoptotic death}

We investigated the mechanism of apoptotic cell death in further detail in the Caki-2 cell line in view of its differential susceptibility to ZOL and PAM. The analysis was undertaken using Kinetworks ${ }^{\mathrm{TM}}$ KAPS gels on 300-600 $\mu \mathrm{g}$ of protein/sample extracted from the cytosol of treated and untreated cells. The immunoblotting 
analyses involved probing with mixes of in-house validated primary antibodies from commercial sources and the application of each mix into a separate lane of a 20-lane multiblotter. This methodology has been published previously (32). However, a number of antibodies are not suitable for this analysis. For this reason, expression of bax and bcl-2 were performed by conventional western blot, and we used a separate assay to evaluate the effects of the two drugs on caspase 3 activation.

The analyses showed that ZOL was a more potent inducer of apoptosis than PAM. There was no differential effect of bax and bcl-2 protein expression as shown by western blot suggesting that the mitochondrial-apoptosome mediated pathway was not activated (data not shown). Furthermore, caspase 3 activation was only observed in cell lines after exposure to ZOL. A representative assay is shown in figure 6 . According to the Kinetiworks gel analysis, table 3, there was a $50 \%$ reduction of AIF (apoptosis-inducing factor) in both treated samples which may have resulted from its translocation into the nucleus. Since CAS (Cellular Apoptosis Susceptibility protein) is thought to be involved in proliferation, further decrease of CAS in ZOL-treated cells compared to PAM-treated cells is consistent with the higher degree of apoptosis induced by ZOL treatment. DFF45, the inhibitor of caspase-activated DNase, showed $\sim 70 \%$ decrease in the ZOL-treated samples versus $\sim 30 \%$ in the PAM-treated sample, in keeping with the higher pro-apoptotic effect seen with ZOL. The reduction of MSH2 in the ZOL-treated sample may have been related to protein translocation into the nucleus for DNA repair caused by the treatment. We attempted to visualise the MSH-2 protein after ZOL and PAM exposure compared to untreated cells using immunofluorescence. We found that the appearance of cells after PAM exposure was similar to controls with concentration of fluorescence in the cell nucleus. After ZOL exposure however, the distribution of $\mathrm{MSH} 2$ protein changed markedly and adopted a peri-nuclear and cytoplasmic distribution, figure 7. Similarly, for PARP-1, its fulllength form p116 exhibited an 81\% decrease in the ZOL-treated sample and more than $400 \%$ increase in the PAM-treated sample, indicating a higher degree of cleavage of PARP, which faciliates the disassembly of cells. Most of caspases tracked in the screen showed more reduction in their pro-forms in the ZOL-treated sample than the PAM treated sample, which in agreement with the higher percentage of apoptotic cells in ZOL-treated sample. The increase of $\mathrm{SOD}(\mathrm{Cu} / \mathrm{Zn})$, superoxide 
dismutase $[\mathrm{Cu}-\mathrm{Zn}]$, in the ZOL-treated sample might have been cellular response to the stronger apoptosis-inducing capability of ZOL. 


\section{Discussion}

Bisphosphonates are potent inhibitors of bone resorption by inhibition of osteoclast function. The more potent nitrogen-containing bisphosphonates achieve this by inhibiting the mevalonate pathway by inhibiting the processing of $\mathrm{G}$ proteins which are essential for cell survival and function. Nitrogen-containing bisphosphonates disrupt intracellular processes and can cause apoptosis. ZOL, in particular, is a potent anti-resorptive nitrogen-containing bisphosphonate which is in regular clinical use for patients with osteoporosis, osteopaenia and cancer-related bone disease. To date, beneficial effects of bisphosphonates have been reported in renal cancer and other malignancies in terms of reduced pain, improved bone healing and reduced risk of pathological fracture. However, there is little published preclinical work to support these clinical benefits of ZOL in renal cancer metastatic to bone. We have demonstrated its marked antiproliferative and apoptotic effects on three renal cell carcinoma cells lines, and its superior efficacy over PAM. Exposure to ZOL results in the induction of apoptosis through non-mitochondrial pathways. One clinical study has shown that treatment with ZOL reduced the risk of pathological fractures in patients with RCC. This study was a subgroup analysis so further work on RCC cell lines is needed. Bisphosphonates reduce skeletal complications of breast cancer, prostate cancer and multiple myeloma. They may also affect tumour cells directly by inhibition of cell invasion or adhesion to bone matrix, or by growth inhibitory and/or apoptotic cell death. The apoptosis-inducing effects have been correlated to the antiresorptive properties of each bisphosphonate. The inhibitory effects of ZOL in vitro has been reported in breast cancer (27), prostate cancer (28) and multiple myeloma (33), pancreas (24). We found evidence of significant antiproliferative effects in a range 10-100 $\mu \mathrm{mol}$, consistent with previous studies. Responses to as little as $1 \mu \mathrm{mol}$ were also found early as 30 minutes in one cell line, and although ZOL was the more effective antiproliferative agent, it appeared to act much later than PAM. The effects of both bisphosphonates were abrogated to a small extent by the addition of isoprenoids suggesting that, similar to other models, these bisphosphonates were able to target the enzymes of the mevalonate pathway (34). The effect was more significant with the co-treatment with FOH than GGOH contrasting with other studies which have shown partial rescue with $\operatorname{GGOH}(35,36)$. 
Exposure of cell lines to ZOL and PAM resulted in different effects on the cell cycle in each line. The more profound pro-apoptotic effect of ZOL was reflected in increases in the subG1 peak in all three cell lines (most pronounced in D69581 and Caki-2). However, PAM was associated with a cytostatic effect as shown by the accumulation of cells in S phase and G2/M. We showed that in parallel with the antiproliferative effects mediated by the drug, ZOL also induces apoptotic cell death in all RCC cell lines. The apoptotic effect did not appear to involve the mitochondrial pathway as expression of bax and bcl-2 proteins were not perturbed. Furthermore, there was no clear evidence of activation of FASL. We found a reduction in AIF after either treatment, and that most of the caspases tracked in the Kinexus gel showed a reduction of their pro forms after ZOL versus PAM treatment, consistent with the higher number of cells undergoing apoptosis. Other findings were also consistent with a more powerful pro-apoptotic effect of ZOL. This included decreases in apoptosis inhibitors CAS and DFF45, and the dramatic reduction in MSH2, a protein involved in DNA mismatch repair. The increase in SOD was consistent with a higher cellular response to the stronger apoptosis-inducing capability of ZOL. There was no evidence of necrotic cell death and no induction of heat shock proteins (data not shown). Our observations for ZOL on RCC lines are consistent with other studies that ZOL-mediated apoptosis is associated with cytochrome $\mathrm{c}$ release and caspase activation. Caspase 3 is involved in the execution phase of apoptosis when proteolysis of intracellular substrates is a major event. Inhibition of caspase 3 prevents osteoclast apoptosis. In keeping with previous reports in breast cancer lines, we found clear evidence that only ZOL was capable of caspase 3 activation.in our cell line (27). Taken together, there is clear evidence of specific cellular effects of ZOL compared to PAM, which will be evaluated in a mouse xenograft model.

Numerous studies suggest suggest direct anticancer effect of bisphosphonates even in the bone microenvironment. The positive effects of bisphosphonate on bone health in vivo is due to their ability to disrupt or alter paracrine interactions in the bone microevironment $(37,38)$. The evidence for this includes observations that bisphosphonates reduce IL-6 expression by osteoblasts (39) and induce soluble inhibitors of osteoclast activity into conditioned media (40). Futhermore, osteoblasts express factors that promote the growth of prostate cancer cells but co-culture of tumour cells and osteoblasts suggest that ZOL is capable of directly inhibiting growth 
of prostate cancer cells even when grown in the presence of an osteoblast cell line (41, 42). However, bisphosphonates may also inhibit osteoclastic bone resorption through increased expression of factors such as osteoprotegerin by normal human osteoblasts (43).

The concentrations required for to achieve effects were as low as $1 \mu \mathrm{mol}$ in our study. The issue of delivering adequate doses of bisphosphonate in clinical studies has been discussed as a potential limitation as the typical serum levels of PAM vary between 0.5-8 $\mu \mathrm{mol}$ depending on the dosage and duration of infusion (44-48). Most in vitro studies like ours have used doses between 10 and $100 \mu$ mol but antitumour effects have been observed in plasma cells and prostate cancer cell lines with doses as low as $1 \mu \mathrm{mol}(35,49)$. However, the local concentrations of bisphosphonates at the sites of active bone resorption may be much higher through their affinity for bone mineral (50). Strategies aimed at targeting higher concentrations of BP to bone using, for example, liposomal mediated delivery may be useful.

\section{Conclusion}

The important contribution of bisphosphonate therapy to the management of bone disease in breast cancer, prostate cancer and multiple myeloma is rapidly leading to its consideration for other malignancies. However, as we have shown in this study, the biological effects may vary depending on cell line and type of bisphosphonate used. We found that RCC cell lines are differentially susceptible to the effects of aminobisphophonates; ZOL is a more potent agent than PAM and ZOL may overcome resistance to PAM. ZOL targets the enzymes of the mevalonate pathway as expected, induces apoptosis through non-mitochondrial pathways but was also associated with high degrees of cellular stress as evidenced by induction of mismatch repair protein and superoxide dismutase. The safety and efficacy of these agents in the supportive treatment of breast cancer, multiple myeloma and prostate cancer justifies their further clinical evaluation in RCC patients. 


\section{Acknowledgements}

We are very grateful to Onyvax Ltd for access the cell line D69581, and to Prof Mike

Clemens and Ian Jeffrey for critical reading of the manuscript and advice on the apoptosis assays. We are also grateful to Novartis Ltd for the initial supply of bisphosphonates for the studies.

\section{References}

1. Zekri J, Ahmed N, Coleman RE, Hancock BW. The skeletal metastatic complications of renal cell carcinoma. Int J Oncol 2001;19(2):379-82.

2. Coleman RE. Skeletal complications of malignancy. Cancer $1997 ; 80(8$ Suppl):1588-94.

3. Miller PD, Watts NB, Licata AA, Harris ST, Genant HK, Wasnich RD, et al. Cyclical etidronate in the treatment of postmenopausal osteoporosis: efficacy and safety after seven years of treatment. Am J Med 1997;103(6):468-76.

4. Reid DM, Hughes RA, Laan RF, Sacco-Gibson NA, Wenderoth DH, Adami $\mathrm{S}$, et al. Efficacy and safety of daily risedronate in the treatment of corticosteroidinduced osteoporosis in men and women: a randomized trial. European Corticosteroid-Induced Osteoporosis Treatment Study. J Bone Miner Res 2000;15(6):1006-13.

5. Roux C, Gennari C, Farrerons J, Devogelaer JP, Mulder H, Kruse HP, et al. Comparative prospective, double-blind, multicenter study of the efficacy of tiludronate and etidronate in the treatment of Paget's disease of bone. Arthritis Rheum 1995;38(6):851-8.

6. Major P, Lortholary A, Hon J, Abdi E, Mills G, Menssen HD, et al. Zoledronic acid is superior to pamidronate in the treatment of hypercalcemia of malignancy: a pooled analysis of two randomized, controlled clinical trials. J Clin Oncol 2001;19(2):558-67.

7. Hortobagyi GN, Theriault RL, Porter L, Blayney D, Lipton A, Sinoff C, et al. Efficacy of pamidronate in reducing skeletal complications in patients with breast cancer and lytic bone metastases. Protocol 19 Aredia Breast Cancer Study Group. N Engl J Med 1996;335(24):1785-91.

8. Lipton A, Theriault RL, Hortobagyi GN, Simeone J, Knight RD, Mellars K, et al. Pamidronate prevents skeletal complications and is effective palliative treatment in women with breast carcinoma and osteolytic bone metastases: long term follow-up of two randomized, placebo-controlled trials. Cancer 2000;88(5):1082-90.

9. Berenson JR, Lichtenstein A, Porter L, Dimopoulos MA, Bordoni R, George $\mathrm{S}$, et al. Efficacy of pamidronate in reducing skeletal events in patients with advanced multiple myeloma. Myeloma Aredia Study Group. N Engl J Med 1996;334(8):48893.

10. Rosen LS, Gordon D, Kaminski M, Howell A, Belch A, Mackey JA, et al. Zoledronic acid versus pamidronate in the treatment of skeletal metastases in patients with breast cancer or osteolytic lesions of multiple myeloma: a phase III, doubleblind, comparative trial. Cancer J 2001;7(5):377-87.

11. Rosen LS, Gordon D, Tchekmedyian S, Yanagihara R, Hirsh V, Krzakowski $\mathrm{M}$, et al. Zoledronic acid versus placebo in the treatment of skeletal metastases in patients with lung cancer and other solid tumors: a phase III, double-blind, 
randomized trial--the Zoledronic Acid Lung Cancer and Other Solid Tumors Study Group. J Clin Oncol 2003;21(16):3150-7.

12. Saad F, Gleason DM, Murray R, Tchekmedyian S, Venner P, Lacombe L, et al. A randomized, placebo-controlled trial of zoledronic acid in patients with hormone-refractory metastatic prostate carcinoma. J Natl Cancer Inst 2002;94(19):1458-68.

13. Lipton A, Zheng M, Seaman J. Zoledronic acid delays the onset of skeletalrelated events and progression of skeletal disease in patients with advanced renal cell carcinoma. Cancer 2003;98(5):962-9.

14. Amin D, Cornell SA, Perrone MH, Bilder GE. 1-Hydroxy-3-

(methylpentylamino)-propylidene-1,1-bisphosphonic acid as a potent inhibitor of squalene synthase. Arzneimittelforschung 1996;46(8):759-62.

15. Luckman SP, Hughes DE, Coxon FP, Graham R, Russell G, Rogers MJ.

Nitrogen-containing bisphosphonates inhibit the mevalonate pathway and prevent post-translational prenylation of GTP-binding proteins, including Ras. J Bone Miner Res 1998;13(4):581-9.

16. Schmidt A, Rutledge SJ, Endo N, Opas EE, Tanaka H, Wesolowski G, et al. Protein-tyrosine phosphatase activity regulates osteoclast formation and function: inhibition by alendronate. Proc Natl Acad Sci U S A 1996;93(7):3068-73.

17. Teronen O, Heikkila P, Konttinen YT, Laitinen M, Salo T, Hanemaaijer R, et al. MMP inhibition and downregulation by bisphosphonates. Ann N Y Acad Sci 1999;878:453-65.

18. Diel IJ, Solomayer EF, Costa SD, Gollan C, Goerner R, Wallwiener D, et al. Reduction in new metastases in breast cancer with adjuvant clodronate treatment. N Engl J Med 1998;339(6):357-63.

19. Pelger RC, Hamdy NA, Zwinderman AH, Lycklama a Nijeholt AA, Papapoulos SE. Effects of the bisphosphonate olpadronate in patients with carcinoma of the prostate metastatic to the skeleton. Bone 1998;22(4):403-8.

20. Tamura H, Ishii S, Ikeda T, Wada N, Enomoto K, Kitajima M. Therapeutic efficacy of pamidronate in combination with chemotherapy to bone metastasis of breast cancer in a rat model. Surg Oncol 1996;5(3):141-7.

21. Santini D, Vincenzi B, Dicuonzo G, Avvisati G, Massacesi C, Battistoni F, et al. Zoledronic acid induces significant and long-lasting modifications of circulating angiogenic factors in cancer patients. Clin Cancer Res 2003;9(8):2893-7.

22. Rogers MJ, Frith JC, Luckman SP, Coxon FP, Benford HL, Monkkonen J, et al. Molecular mechanisms of action of bisphosphonates. Bone 1999;24(5 Suppl):73S$79 \mathrm{~S}$.

23. Aparicio A, Gardner A, Tu Y, Savage A, Berenson J, Lichtenstein A. In vitro cytoreductive effects on multiple myeloma cells induced by bisphosphonates. Leukemia 1998;12(2):220-9.

24. Tassone P, Tagliaferri P, Viscomi C, Palmieri C, Caraglia M, D'Alessandro A, et al. Zoledronic acid induces antiproliferative and apoptotic effects in human pancreatic cancer cells in vitro. Br J Cancer 2003;88(12):1971-8.

25. Hiraga T, Ueda A, Tamura D, Hata K, Ikeda F, Williams PJ, et al. Effects of oral UFT combined with or without zoledronic acid on bone metastasis in the 4T1/luc mouse breast cancer. Int J Cancer 2003;106(6):973-9.

26. Kuroda J, Kimura S, Segawa H, Kobayashi Y, Yoshikawa T, Urasaki Y, et al. The third-generation bisphosphonate zoledronate synergistically augments the anti$\mathrm{Ph}+$ leukemia activity of imatinib mesylate. Blood 2003;102(6):2229-35. 
27. Senaratne SG, Mansi JL, Colston KW. The bisphosphonate zoledronic acid impairs membrane localisation and induces cytochrome $\mathrm{c}$ release in breast cancer cells. Br J Cancer 2002;86(9):1479-86.

28. Lee MV, Fong EM, Singer FR, Guenette RS. Bisphosphonate treatment inhibits the growth of prostate cancer cells. Cancer Res 2001;61(6):2602-8.

29. Nishiyama Y, Suwa H, Okamoto K, Fukumoto M, Hiai H, Toyokuni S. Low incidence of point mutations in $\mathrm{H}-, \mathrm{K}$ - and $\mathrm{N}$-ras oncogenes and $\mathrm{p} 53$ tumor suppressor gene in renal cell carcinoma and peritoneal mesothelioma of Wistar rats induced by ferric nitrilotriacetate. Jpn J Cancer Res 1995;86(12):1150-8.

30. Fujita J, Kraus MH, Onoue H, Srivastava SK, Ebi Y, Kitamura Y, et al. Activated H-ras oncogenes in human kidney tumors. Cancer Res 1988;48(18):5251-5. 31. Rosen LS, Gordon D, Tchekmedyian NS, Yanagihara R, Hirsh V, Krzakowski $\mathrm{M}$, et al. Long-term efficacy and safety of zoledronic acid in the treatment of skeletal metastases in patients with nonsmall cell lung carcinoma and other solid tumors: a randomized, Phase III, double-blind, placebo-controlled trial. Cancer 2004;100(12):2613-21.

32. Pelech S, Sutter C, Zhang H. Kinetworks protein kinase multiblot analysis. Methods Mol Biol 2003;218:99-111.

33. Shipman CM, Rogers MJ, Apperley JF, Graham R, Russell G, Croucher PI. Anti-tumour activity of bisphosphonates in human myeloma cells. Leuk Lymphoma 1998;32(1-2):129-38.

34. Oades GM, Senaratne SG, Clarke IA, Kirby RS, Colston KW. Nitrogen containing bisphosphonates induce apoptosis and inhibit the mevalonate pathway, impairing Ras membrane localization in prostate cancer cells. J Urol 2003;170(1):246-52.

35. Coxon JP, Oades GM, Kirby RS, Colston KW. Zoledronic acid induces apoptosis and inhibits adhesion to mineralized matrix in prostate cancer cells via inhibition of protein prenylation. BJU Int 2004;94(1):164-70.

36. Virtanen SS, Vaananen HK, Harkonen PL, Lakkakorpi PT. Alendronate inhibits invasion of PC-3 prostate cancer cells by affecting the mevalonate pathway. Cancer Res 2002;62(9):2708-14.

37. Nishikawa M, Akatsu T, Katayama Y, Yasutomo Y, Kado S, Kugal N, et al. Bisphosphonates act on osteoblastic cells and inhibit osteoclast formation in mouse marrow cultures. Bone 1996;18(1):9-14.

38. Sahni M, Guenther HL, Fleisch H, Collin P, Martin TJ. Bisphosphonates act on rat bone resorption through the mediation of osteoblasts. J Clin Invest 1993;91(5):2004-11.

39. Derenne S, Amiot M, Barille S, Collette M, Robillard N, Berthaud P, et al. Zoledronate is a potent inhibitor of myeloma cell growth and secretion of IL-6 and MMP-1 by the tumoral environment. J Bone Miner Res 1999;14(12):2048-56.

40. Vitte C, Fleisch H, Guenther HL. Bisphosphonates induce osteoblasts to secrete an inhibitor of osteoclast-mediated resorption. Endocrinology 1996; 137(6):2324-33.

41. Ritchie CK, Andrews LR, Thomas KG, Tindall DJ, Fitzpatrick LA. The effects of growth factors associated with osteoblasts on prostate carcinoma proliferation and chemotaxis: implications for the development of metastatic disease. Endocrinology 1997; 138(3):1145-50.

42. Giunciuglio D, Cai T, Filanti C, Manduca P, Albini A. Effect of osteoblast supernatants on cancer cell migration and invasion. Cancer Lett 1995;97(1):69-74. 
43. Viereck V, Emons G, Lauck V, Frosch KH, Blaschke S, Grundker C, et al. Bisphosphonates pamidronate and zoledronic acid stimulate osteoprotegerin production by primary human osteoblasts. Biochem Biophys Res Commun 2002;291(3):680-6.

44. Daley-Yates PT, Dodwell DJ, Pongchaidecha M, Coleman RE, Howell A. The clearance and bioavailability of pamidronate in patients with breast cancer and bone metastases. Calcif Tissue Int 1991;49(6):433-5.

45. Dodwell DJ, Abbas SK, Morton AR, Howell A. Parathyroid hormone-related protein(50-69) and response to pamidronate therapy for tumour-induced hypercalcaemia. Eur J Cancer 1991;27(12):1629-33.

46. Leyvraz S, Hess U, Flesch G, Bauer J, Hauffe S, Ford JM, et al.

Pharmacokinetics of pamidronate in patients with bone metastases. J Natl Cancer Inst 1992;84(10):788-92.

47. Chen T, Berenson J, Vescio R, Swift R, Gilchick A, Goodin S, et al.

Pharmacokinetics and pharmacodynamics of zoledronic acid in cancer patients with bone metastases. J Clin Pharmacol 2002;42(11):1228-36.

48. Legay F, Gauron S, Deckert F, Gosset G, Pfaar U, Ravera C, et al. Development and validation of a highly sensitive RIA for zoledronic acid, a new potent heterocyclic bisphosphonate, in human serum, plasma and urine. J Pharm Biomed Anal 2002;30(4):897-911.

49. Gordon S, Helfrich MH, Sati HI, Greaves M, Ralston SH, Culligan DJ, et al. Pamidronate causes apoptosis of plasma cells in vivo in patients with multiple myeloma. Br J Haematol 2002;119(2):475-83.

50. Sato M, Grasser W, Endo N, Akins R, Simmons H, Thompson DD, et al. Bisphosphonate action. Alendronate localization in rat bone and effects on osteoclast ultrastructure. J Clin Invest 1991;88(6):2095-105. 


\section{$\underline{\text { Figure Legends }}$}

Figure 1. The effect of bisphosphonates on cell survival. 769-P, Caki-2 and D69581 cells were seeded at a density of $1 \times 10^{4}$ in 96-well plates and allowed to adhere overnight. Media was then replaced with $100 \mu \mathrm{l} /$ well media containing ZOL, PAM. or clodronate. At time points 48 and $72 \mathrm{~h}$ after drug addition an MTS assay was performed. The error bars represent 2 standard errors (SE). All experiments were repeated at least 4 times.

Figure 2. Cell survival after exposure to different concentrations of bisphosphonates for up to 72 hours. Cells were seeded at a density of $1 \times 10^{4}$ in 96-well plates and allowed to adhere overnight. Media was then replaced with $100 \mu 1 /$ well media containing $0 \mu \mathrm{M}, 10 \mu \mathrm{M}$ or $100 \mu \mathrm{M}$ of ZOL or PAM. An MTS assay was performed after $0.5,1,3$ and 24,48 and 72 hours after drug exposure. The error bars represent the standard deviation of triplicate wells. All experiments were repeated 4 times, and the error bars represent 2SE. Representative examples for the 769P and D69581 cell lines are shown.

Figure 3. The effect of isoprenoids on loss of cell viability after exposure to bisphosphonates. Cells were plated at $1 \times 104 / \mathrm{ml}$ in 24 well plates and allowed to adhere overnight and treated. Farnesol $(\mathrm{FOH})$ or geranylgeroniol $(\mathrm{GGOH})$ were added for 3 hours prior to exposure to bisphosphonate. After 24 hours, culture medium was changed and $40 \mathrm{mM}$ of either FOH or GGOH was added. Cells were evaluated at day 4 for viability by MTS assay. All experiments were repeated 3 times. Representative examples of treatment with $\mathrm{ZOL}$ and $\mathrm{FFOH} / \mathrm{GGOH}$ is shown. Addition of isoprenoids resulted in increase cell viability for both ZOL and PAM treatments and reached statistical significance with ZOL and FOH $(\mathrm{p}<0.012)$.

Figure 4. Morphological changes in cell lines after exposure to bisphosphonates. Changes were more marked after ZOL exposure and typical of apoptosis (cell shrinkage and blebbing of cell surface). There was early loss of adherence in the 769-P cell line. 
Figure 5. Cell cycle analysis using the Apo Direct assay on untreated control cells and after 72 hour exposure to ZOL and PAM. Each experiment was repeated at least 3 times, results are shown with standard deviations.

Figure 6. Caspase 3 activation assay for Caki-2 cell line exposed to PAM and ZOL for 72 hours. Clear evidence of caspase 3 activation is seen only after exposure to ZOL.

Figure 7. Localisation of MSH-2 protein after treatment with bisphosphonates using immunofluorescence microscopy. The distribution of MSH-2 protein was very similar in control (A) and PAM-treated cells (B) with expression restricted to the nucleus. After ZOL exposure however, the distribution of MSH2 protein changed markedly and adopted a peri-nuclear and cytoplasmic distribution (C).

\section{Table Legend}

Table 1. Assessment of apoptotic effect of bisphosphonates at 72 hours using Apo Direct assay. Analysis of 3 repeated experiments is shown.

Table 2. Kinetiworks analysis of apoptosis protein expression of caki-2 cell lines after exposure to PAM and ZOL compared to untreated cells. All numerical values are relative to control (untreated) cell line. Percentage change in expression compared to control is shown in parentheses, a minus value indicates a reduction in expression. 
ZOL 48 h

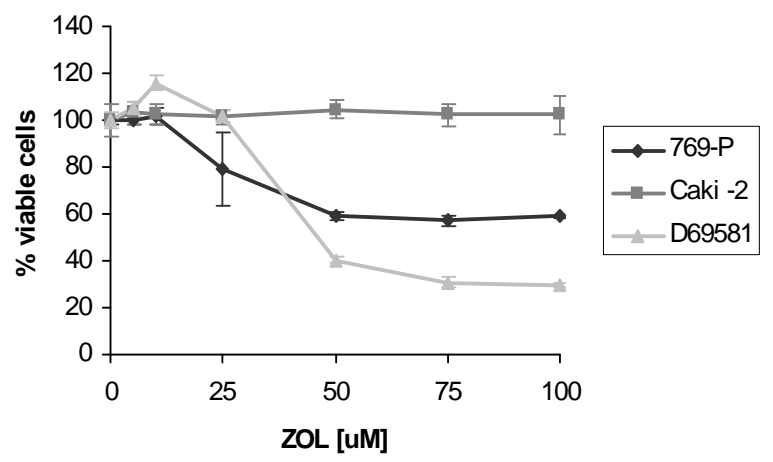

PAM $48 \mathrm{~h}$
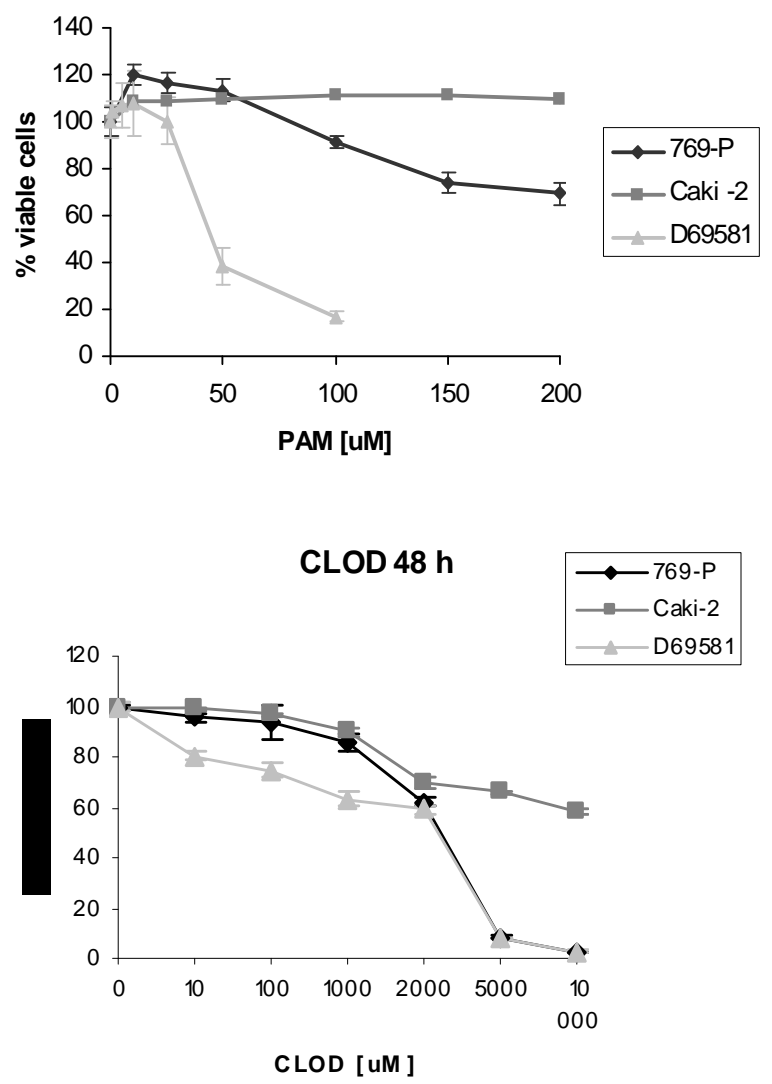

Figure 1
ZOL 72 h

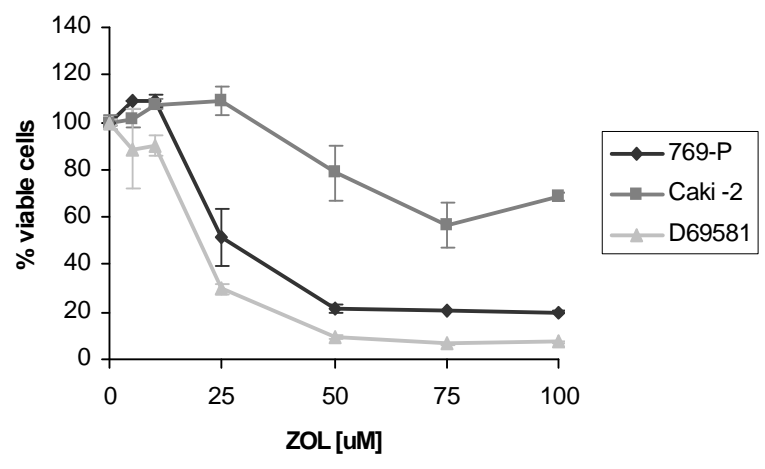

PAM 72 h

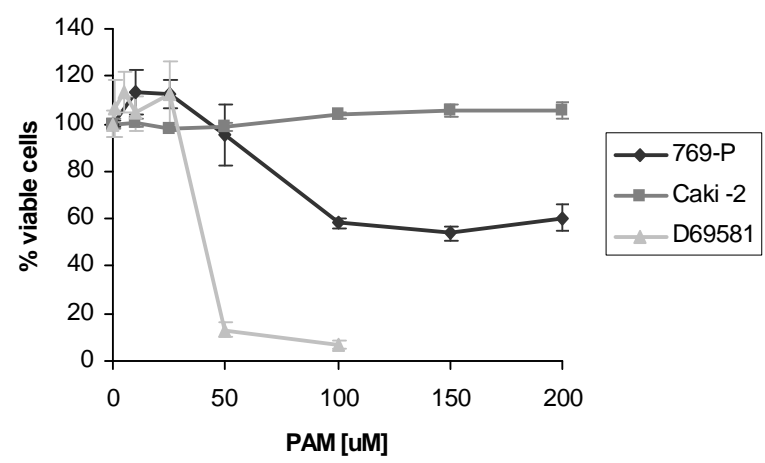

CLOD 72 h

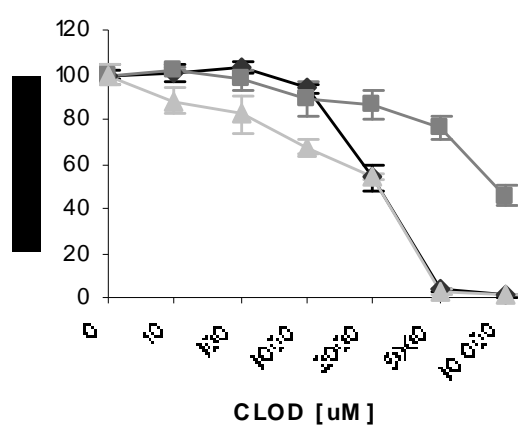




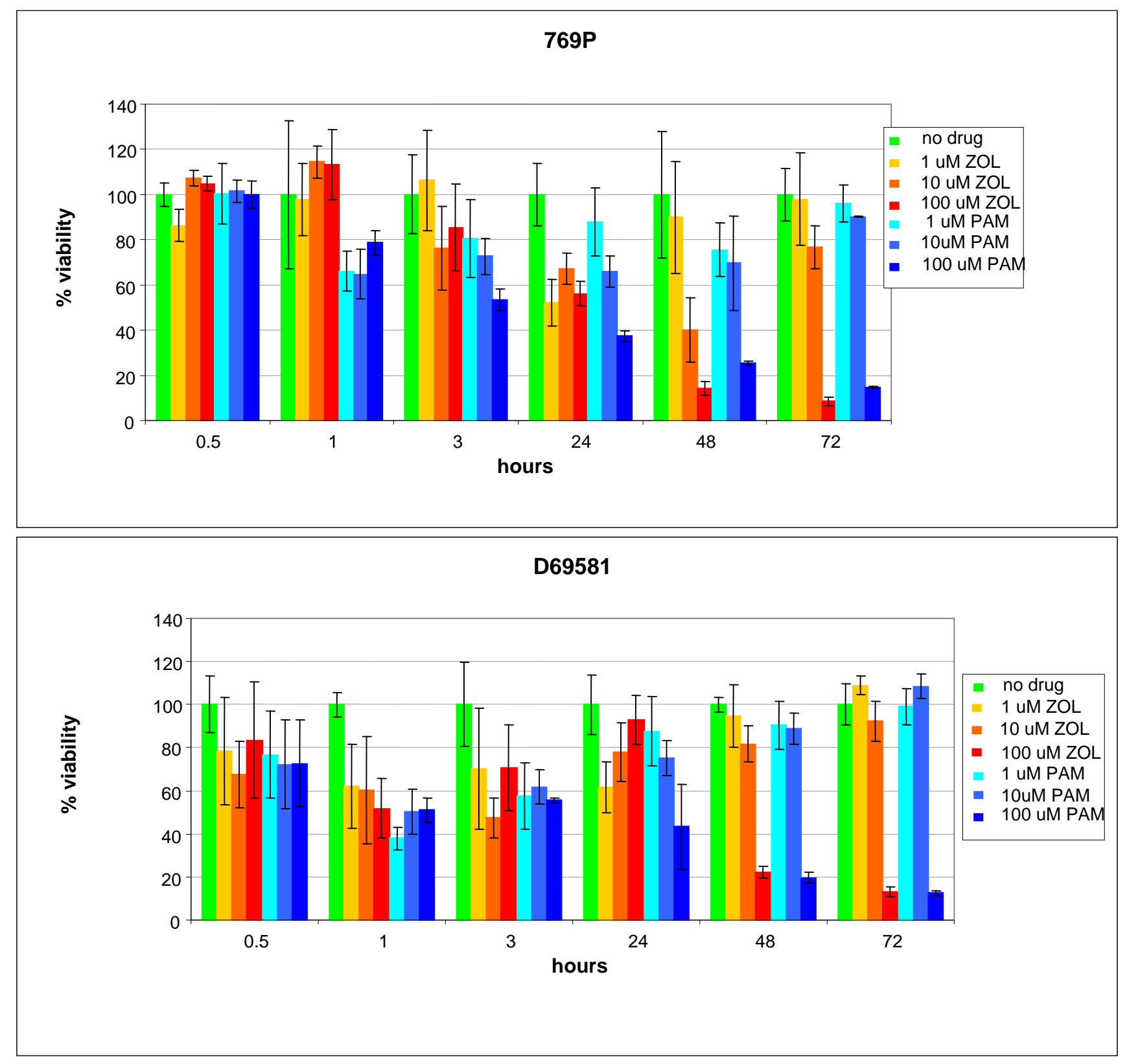

Figure 2 


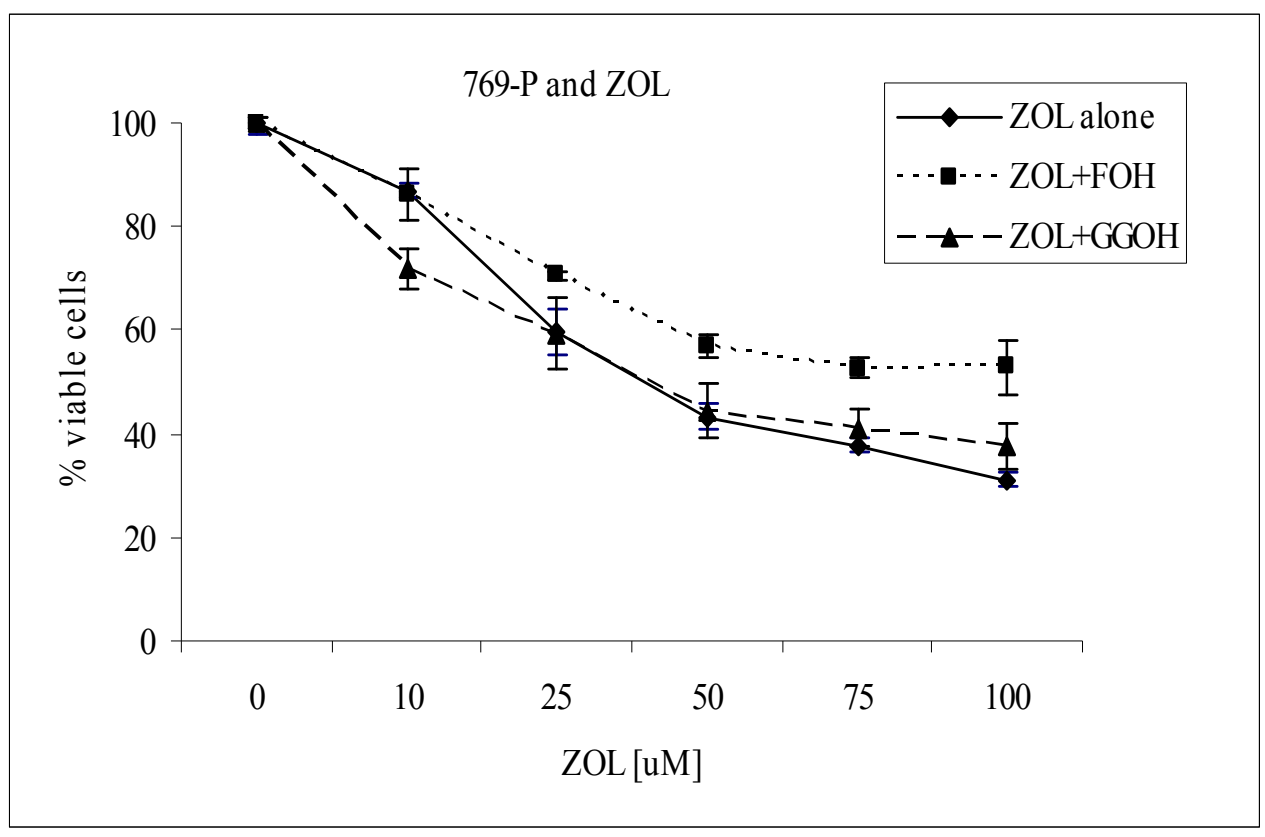

Figure 3 


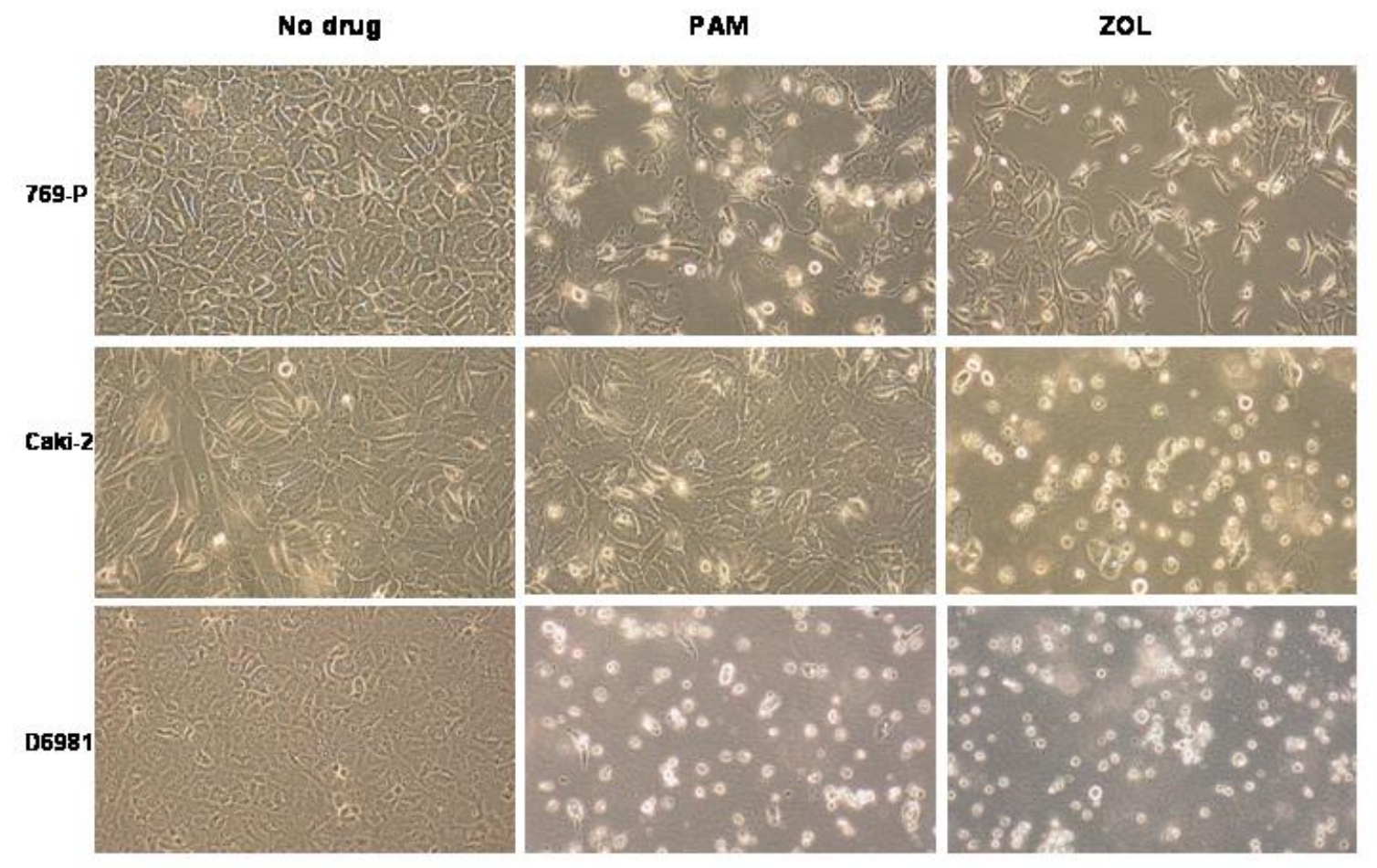

Figure 4 


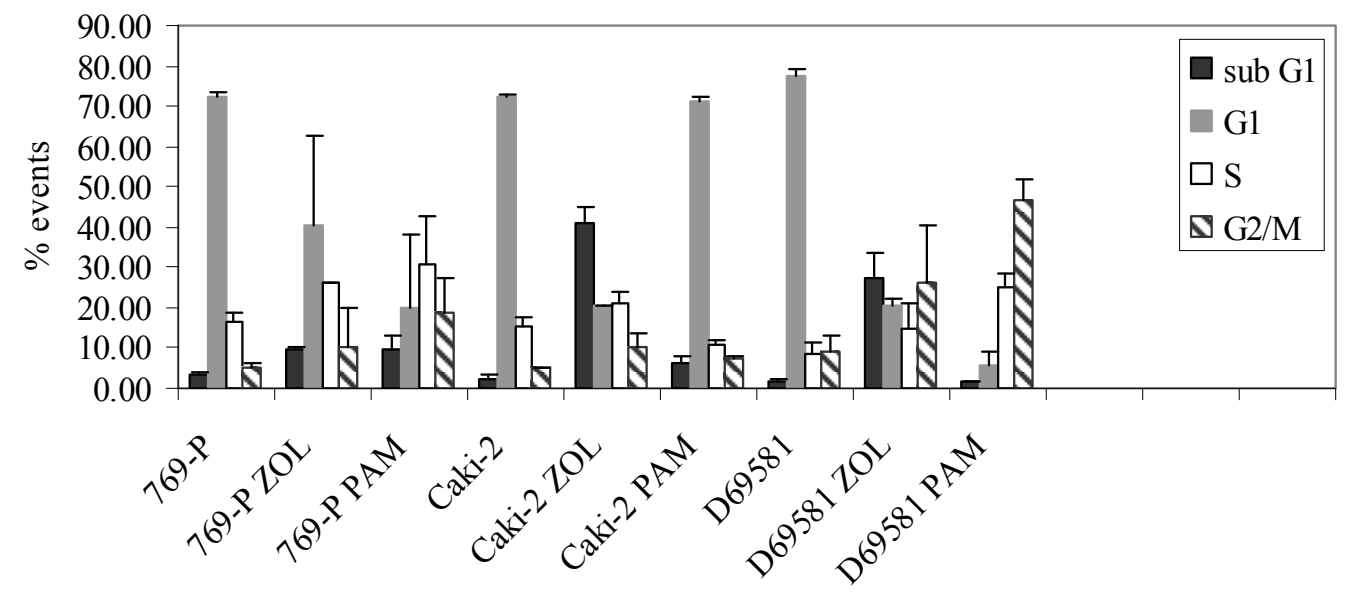

Figure 5 
Caspase- 3 activity of Caki- 2 cells

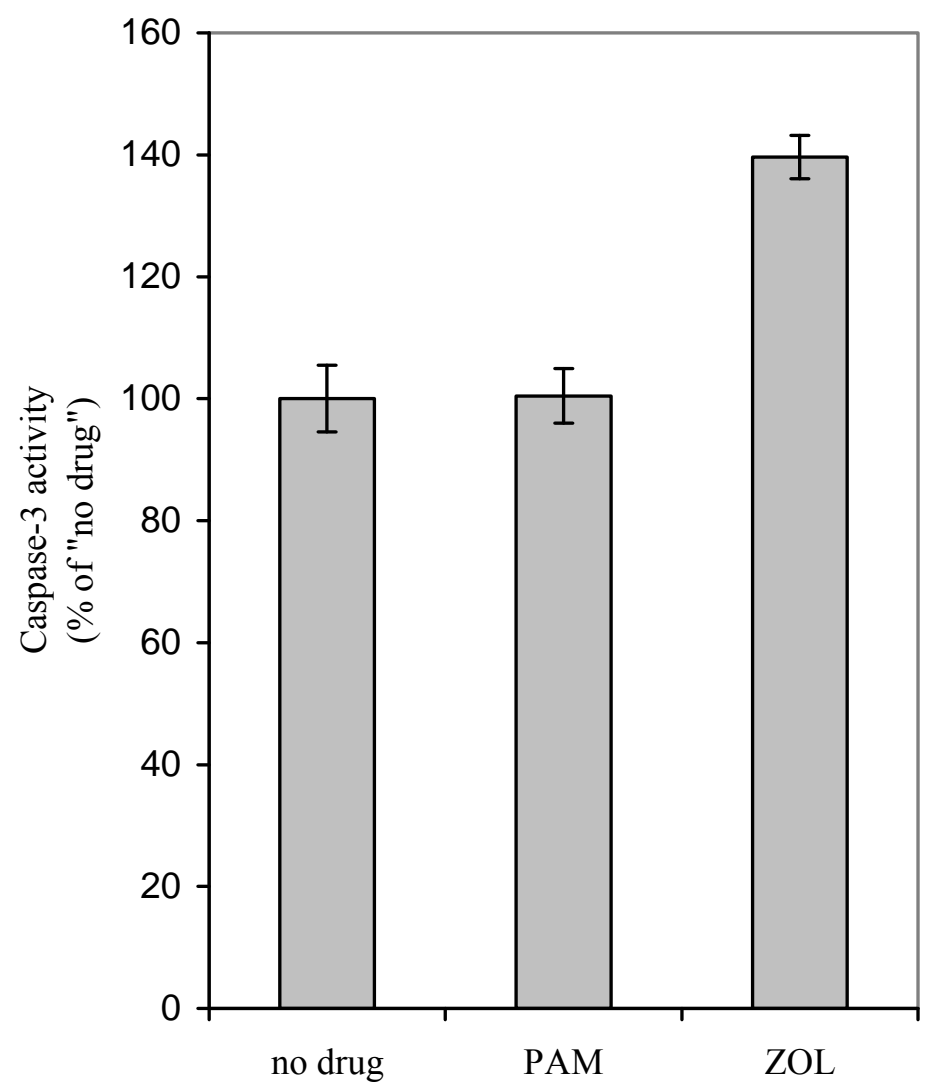

Figure 6 
A
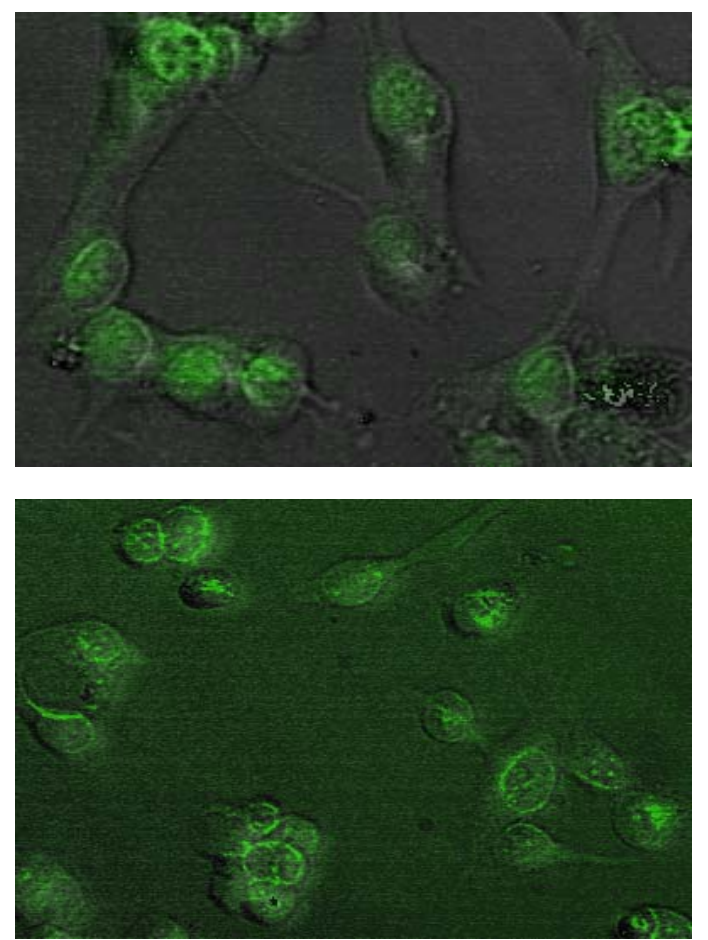

C

B

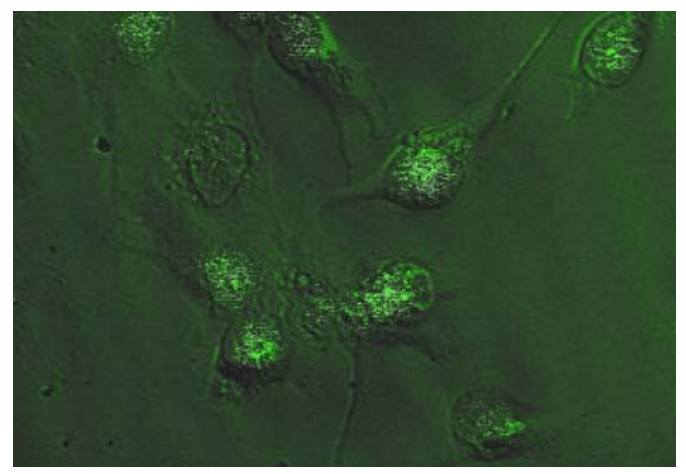

Figure 7 
Table 1 .

$\%$ apoptosis

\begin{tabular}{lrrr} 
& $769 \mathrm{P}$ & Caki2 & D6981 \\
\hline & & & \\
Untreated & 1.5 & 2.5 & 2.7 \\
St dev & 0.20 & 2.05 & 0.88 \\
Error & 0.12 & 1.18 & 0.51 \\
& & & \\
& & & \\
ZOL & 74.6 & 95.3 & 94.0 \\
St dev & 20.74 & 2.08 & 5 \\
Error & 11.97 & 1.2 & 2.88 \\
& & & \\
& & & \\
PAM & 51.3 & 4.7 & 83.3 \\
St dev & 22.50 & 3.92 & 8.14 \\
Error & 12.99 & 2.26 & 4.70 \\
& & &
\end{tabular}


Table 2.

\begin{tabular}{|c|c|c|c|}
\hline \multirow[t]{2}{*}{ Protein } & \multicolumn{3}{|c|}{ Treatment } \\
\hline & Control & PAM & $\mathrm{ZOL}$ \\
\hline AIF & 1125 & $622(-44.7)$ & $557(-50.4)$ \\
\hline CAS & 683 & $334(-51)$ & $61(-91)$ \\
\hline CASP2 p12 & 193 & $93(-51.8)$ & undetectable \\
\hline CASP5 int & 9481 & $9970(4.9)$ & $9235(-2.5)$ \\
\hline CASP5 p20 & 4188 & $7016(40.3)$ & $2947(29.6)$ \\
\hline Cytochrome C & 1161 & $716(-38.3)$ & $658(-43.3)$ \\
\hline DAXX & 325 & $415(27.6)$ & $58(-82.2)$ \\
\hline DFF45-L & 1025 & $777(-24)$ & $305(-70.2)$ \\
\hline DFF45-S & 354 & $237(-33)$ & $91(-74.3)$ \\
\hline FasL & 1513 & $1189(-21.4)$ & $1854(18.3)$ \\
\hline MSH2 & 1011 & $772(-23.6)$ & $181(-82.1)$ \\
\hline PARP p116 & 162 & $847(80.8)$ & $31(-80.8)$ \\
\hline PARP p89 & 233 & $69(-70.3)$ & $239(2.5)$ \\
\hline PERP & 2219 & $3047(27.1)$ & $1174(-47.1)$ \\
\hline proCASP1 alpha & 548 & $419(-24.9)$ & $131(-76.1)$ \\
\hline proCASP1 beta & 814 & $715(-12.1)$ & $407(-50)$ \\
\hline proCASP12 & 736 & $743(0.9)$ & $624(-15.2)$ \\
\hline proCASP3 & 1041 & $543(-47.8)$ & $233(-77.6)$ \\
\hline proCASP4 & 383 & $223(-41.8)$ & $72(-81.2)$ \\
\hline proCASP6 & 518 & $273(-47.2)$ & $149(-71.2)$ \\
\hline proCASP7 & 1168 & $1680(30.4)$ & $1648(29.1)$ \\
\hline proCASP8 & 6638 & $3767(-43.2)$ & $2521(-62)$ \\
\hline proCASP9 & 342 & $312(-8.7)$ & $227(-33.6)$ \\
\hline SOCS4 & 266 & 407 (34.6) & $547(51.3)$ \\
\hline $\operatorname{SOD}(\mathrm{Cu} / \mathrm{Zn})$ & 20960 & 23109 (9.2) & $46246(54.6)$ \\
\hline SODD & 321 & $174(-45.8)$ & $126(-60.7)$ \\
\hline XIAP & 136 & $111(-18)$ & undetectable \\
\hline
\end{tabular}

